\title{
Er tidlig ultralydundersøkelse for alle et gode?
}

\author{
Debatten raser rundt innføring av tidlig ultralydundersøkelse. Flere politiske partier signaliserer at de vil \\ gå inn for dette som tilbud til alle gravide. De hevder et rutinemessig tilbud er mer rettferdig og at det gir økt \\ valgfrihet. Er dette tilfellet? Eller vil det gi økt abortpress og pålegge kvinner ansvar for at barnet de setter \\ til verden har de rette egenskaper?
}

Jeg er vant til å bruke ordet rettferdig i relasjon til goder, ikke onder.

Kombinert ultralydundersøkelse/blodprøver (KUB) som screening er ingen god undersøkelse for gravide under 35 år. I en stor finsk studie var $97 \%$ av positive svar hos kvinner under 35 år falskt positive (1). Disse vil i nesten alle tilfeller etterfølges av invasiv diagnostikk, med risiko for spontanabort på 0,5-2\% (2). Hos unge kvinner oppdages et foster med Downs syndrom ved invasiv diagnostikk for om lag hvert friske foster som spontanaborteres (1). Videre vil det store antallet kvinner som opplever falskt positive prøver kunne føle $ø$ kt engstelse gjennom svangerskapet, trass $i$ at mistanke om kromosomavvik er avkreftet $(3,4)$.

Hos yngre kvinner vil $35 \%$ av tilfeller med Downs syndrom ikke oppdages, de er falskt negative (1). I denne gruppen sliter foreldrene mer med å tilpasse seg livet med et barn med Downs syndrom, de opplever det som mer stressende, og de har større behov for å klandre andre, enn foreldre som ikke har fått utført fosterdiagnostikk (5).

Jeg mener derfor at kombinert ultralydundersøkelse/blodprøver som screening er dårlig medisin, faktisk med negativ helseeffekt for de yngre, altså et onde. Hvem ønsker rettferdig fordeling av et onde vi lett kan unngå?

\section{Får kvinner økt valgfrihet?}

Umiddelbart høres det kanskje slik ut, men jeg vil hevde at vi har større valgfrihet med dagens ordning, hvor man henvises til kombinert ultralydundersøkelse/blodprøver på medisinsk indikasjon. I det øyeblikk man innfører dette for alle, vil valgfriheten i praksis forsvinne. Det blir raskt et tilbud kvinnen ikke kan avslå. Norske gravide er pliktoppfyllende - minst $98 \%$ tar imot tilbudet om rutineultralydundersøkelse (6). Jeg vil tro at de fleste gravide har fătt med seg uttalelser fra politikere og journalister om at tidlig ultralydundersøkelse kan redde liv.

Det hjelper ikke hvor mange av oss som har argumentert imot. Gravide vil derfor være skeptiske til å takke nei. Danmark har hatt et tilbud om kombinert ultralydundersøkelse/blodprøver til alle fra 2005, der er oppmøteprosenten på 93(7). Det er ingen grunn til å tro at tallet blir lavere i Norge.

\section{Likhet?}

Likhetsargumentet er også brukt - det hevdes at ressurssterke kvinner i storbyene kjøper seg undersøkelsen. Dette har ingen klart å vise, ei heller om det faktisk er fosterdiagnostisk ultralydundersøkelse de kjøper (noe som er forbudt uten medisinsk indikasjon). Tall viser at kun $10 \%$ av norske gravide i 2008-09 fikk utført fosterdiagnostisk utredning (8).

\section{Medfører tilbud til alle abortpress?}

Jeg mener det. Der avvik er påvist, har man frihet til å velge ett alternativ - abort. Flere kvinner jeg har snakket med, opplever at det ikke er lagt opp til å bære frem barnet, det nevnes ikke som alternativ. For dem som velger det, oppleves oppfølgingen svært tilfeldig, oftest mangelfull.

Det finnes ikke norske studier som viser hvordan kvinner blir informert når avvik påvises i svangerskapet. Flere gravide har fortalt meg om negativt vinklet rådgivning, ingen om det motsatte. Ensidig negativ veiledning synes heller å være normen enn unntaket $(9,10)$. Leger som ser på selektiv abort som problematisk, fritas for veiledningsoppgaver. Resultatet blir at veiledning utføres av leger som ser på selektiv abort

\section{«Hvem ønsker rettferdig fordeling av et onde vi lett kan unngå?»}

som lite problematisk. Min erfaring er at deres holdninger ofte skinner gjennom og legger føringer for hva som forventes av den gravide. Utenlandske studier indikerer at helsepersonell generelt er mer positive til selektiv abort enn befolkningen for øvrig $(11,12)$.

Min erfaring er at informasjonen den gravide får når det er påvist alvorlige avvik, preges av en dødelig språkbruk. Tilstander hvor godt over $10 \%$ av barna lever lenger enn et år, betegnes som «dødelige» eller «uforenlig med liv» $(9,10,13,14)$. Utenlandske studier har vist at den preges av sannsynlighetsberegninger de gravide ikke klarer å tolke (4), samt problematisering av det å sette til verden et barn med mentale avvik (9). De gravide får sjelden positiv informasjon om det å bære frem eller å leve med et slikt barn $(9,13)$.

Ved å innføre kombinert ultralydundersøkelse/ blodprøver for alle, sendes signaler om hva som forventes av oss - Downs syndrom ses på som så ille at staten anser det som et gode å gi alle mulighet til å abortere disse fostrene. Svaret blir altså ja i mine øyne; gravide utsettes for et abortpress, både via tilbud om kombinert ultralydundersøkelse/blodprøver for alle, via veiledningen og via mangel på alternative tilbud.

Studier viser at når tilbud om perinatalt hospiceprogram gis som et alternativt valg til abort, velger langt flere å bære frem barnet (15). Et opplegg for perinatal palliasjon burde vært på plass i Norge, all den tid vi tilbyr fosterdiagnostikk til utvalgte grupper. Det ville etter min mening føre til minket abortpress.

\section{Vil kvinnen holdes ansvarlig for barnets helsetilstand?}

Allerede i svangerskapet føler mange at de holdes ansvarlig for å bære frem barn med avvik. Det finnes ikke et opplegg for å følge dem opp og ivareta deres behov i et vanskelig svangerskap. De er påført kunnskap om fosteret som er tung å bære. Min erfaring er at kvinnene det gjelder, ikke får hjelp til å håndtere dette.

Flere forteller at de må forsvare sitt valg overfor helsepersonell. Noen får høre at barnet deres opptar ressurser som burde vært brukt på «normale» barn. Atter andre opplever at barnet blir dårligere behandlet. Dagens praksis synes å være ikke å overvåke fostre med trisomi $13 \mathrm{og} 18 \mathrm{samt}$ andre alvorlige avvik under fødselen og å nekte kvinnen sectio på fosterets indikasjon. Jeg er også blitt fortalt, og har selv erfart, at det er vanlig å unnlate resuscitering av nyfødte med kjent alvorlig avvik (trisomi 13 og 18), samt å unngå all behandling da det vurderes som «dødsutsettende». Studier viser at ved misdannelser i sentralnervesystemet avsluttes behandling hyppigere (16), i tilfeller der utviklingsavvik er kjent på forhånd, unnlater man oftest å behandle $(14,17)$. I debatten rundt fosterdiagnostikk brukes kvinners autonomi som et av hovedargumentene. Det snakkes så fint om at bare kvinnen vet hva som er 
best for seg og sitt foster. Idet kvinnen velger å bære frem barnet, derimot, fratas hun denne autonomien. Hun får ikke være med på avgjørelser om forløsning eller behandlingsnivå $(10,14,17)$. Helsevesenet har ikke lenger tillit til at hun vet hva som er best for seg og sitt barn.

Hvordan skal vi kunne anbefale kvinner å bære frem barnet når dette er tilfellet? Det sender så kraftige signaler om at barnet ikke er verdt ressursbruken, at det ikke er verdt å satse på, på noe vis.

\section{«Allerede i svanger- skapet føler mange at de holdes ansvarlig for å bære frem barn med avvik»}

Kvinner som bærer frem barn med alvorlige avvik beretter om møter med leger som klart gir uttrykk for at de burde ha valgt abort. Hvordan skal kvinner unngå å føle at de har seg selv å takke og at de ikke kan forvente mye hjelp fra helsevesenet når de møter slike holdninger kombinert med mangelfull oppfølging? Mange forteller at de også overfor omgivelsene må forsvare sitt valg, de blir spurt om hvorfor de ikke brukte kunnskapen om fostret til å fjerne det.

Vi ser tendensen i nettdebatter - vi klandres for å sette ressurskrevende barn til verden, vi kalles egoister. Leger står frem i mediene og hevder at vi nærmest er forpliktet til å abortere fostre som kan komme til å lide (18). Slike holdninger vil ikke avta når staten setter i gang aktivt søk etter fostre med avvik.

\section{Siri Fuglem Berg}

sirifberg@gmail.com

Siri Berg (f. 1969) er dr.med. og spesialist $i$ anestesiologi. Hun har selv båret frem et barn med trisomi 18 og siste halvannet år drevet støttevirksomhet for kvinner som får en alvorlig diagnose i svangerskapet, via nettstedet www.trisomi18.com («Omsorg i mors liv») og via amerikanske nettsteder.

\section{Litteratur}

1. Marttala J, Ranta JK, Kaijomaa M et al. More inva sive procedures are done to detect each case of Down's syndrome in younger women. Acta Obstet Gynecol Scand 2011: 90: 642-7.

2. Ullevål universitetssykehus. Fosterdiagnostikk. http://old.ulleval.no/modules/module_123/proxy. asp?ilnfold=7741\&iCategoryld=541\&iDisplayType $=2(21.5 .2012)$.

3. Georgsson Ohman S, Saltvedt S, Grunewald C et al. Does fetal screening affect women's worries about the health of their baby? A randomized controlled trial of ultrasound screening for Down's syndrome versus routine ultrasound screening. Acta Obstet Gynecol Scand 2004; 83: 634-40.

4. Georgsson Ohman S, Grunewald C, Waldenström $U$. Perception of risk in relation to ultrasound screening for Down's syndrome during pregnancy. Midwifery 2009: 25: 264-76.

5. Hall S, Bobrow M, Marteau TM. Psychological consequences for parents of false negative results on prenatal screening for Down's syndrome: retrospective interview study. BMJ 2000; 320: 407-12.

6. Reinar LM, Smedslund G. Fretheim A et al. Rutinemessig ultralydundersøkelse i svangerskapet. Rapport fra Kunnskapssenteret nr. 11-2008Systematisk oversikt. Oslo: Kunnskapssenteret 2008. www.kunnskapssenteret.no/Publikasjoner/ Rutinemessig+ultralydunders $\varnothing$ kelse+i+ svangerskapet.2759.cms (30.5.2012).
7. Norsk Gynekologisk Forening. Nyheter. 2012 Tidleg ultralyd i svangerskapsomsorga. http:// legeforeningen.no/fagmed/norsk-gynekologiskforening/nyheter/2012/tidlig-ultralyd-isvangerskapsomsorgen/ (21.5.2012).

8. Lauvrak V, Norderhaug IN, Hagen G et al. Tidlig ultralyd i svangerskapsomsorgen. Notat fra Kunn skapssenteret. Oslo: Kunnskapssenteret, 2012. www.kunnskapssenteret.no/Publikasjoner/ Tidlig+ultralyd+i+svangerskapsomsorgen. 14395.cms?threepagenor=1 (30.5.2012).

9. Farrelly E, Cho MK, Erby L et al. Genetic counseling for prenatal testing: Where is the discussion about disability? J Genet Counsel 2012; e-publisert 2.2.

10. Wilkinson D. Fatal fetal paternalism. J Med Ethics 2012; e-publisert 19.1

11. Drake H, Reid M, Marteau T. Attitudes towards termination for fetal abnormality: comparisons in three European countries. Clin Genet 1996; 49: 134-40.

12. Mishori Dery A, Carmi R, Shoham Vardi I. Attitudes toward the acceptability of reasons for pregnancy termination due to fetal abnormalities among prenatal care providers and consumers in Israel. Prenat Diagn 2008; 28: 518-24.

13. Koogler TK, Wilfond BS, Ross LF. Lethal language, lethal decisions. Hastings Cent Rep 2003; 33 : 37-41.

14. McCaffrey MJ. Lethality begets lethality. J Perinatol 2011; 31: 630-1, author reply 631-2

15. Balaguer A, Martín-Ancel A, Ortigoza-Escobar D et al. The model of Palliative Care in the perinatal setting: a review of the literature. BMC Pediatr 2012; 12: 25

16. Syvertsen L, Bratlid D. Avslutning av behandling ved alvorlig sykdom hos nyfødte. Tidsskr Nor Lægeforen 2004; 124: 2483-5.

17. McGraw MP, Perlman JM. Attitudes of neonatologists toward delivery room management of confir med trisomy 18: potential factors influencing a changing dynamic. Pediatrics 2008. 121: 1106-10.

18. TV2 nyhetene. Lege i abortdebatten: - Syke barn bør slippe å bli født www.tv2.no/nyheter/innenriks/ helse/lege-i-abortdebatten-syke-barn-boerslippe-aa-bli-foedt-3750817.html (21.5.2012).

Mottatt 25.4. 2012, første revisjon innsendt 18.5. 2012, godkjent 6.6. 2012. Medisinsk redaktør Siri Lunde. 